Article

\title{
Density of Seasonal Snow in the Mountainous Environment of Five Slovak Ski Centers
}

\author{
Michal Mikloš ${ }^{1, *}$, Jaroslav Skvarenina ${ }^{1, *}$, Martin Jančo ${ }^{2}$ and Jana Skvareninova ${ }^{3}$ \\ 1 Department of Natural Environment, Faculty of Forestry, Technical University in Zvolen, \\ Ul. T.G. Masaryka 24, 96053 Zvolen, Slovakia \\ 2 Institute of Hydrology, Slovak Academy of Sciences, Dúbravská cesta 9, 84104 Bratislava, Slovakia; \\ martinjanco11@gmail.com \\ 3 Faculty of Ecology and Environmental Sciences, Technical University in Zvolen, Ul. T.G. Masaryka 24, \\ 96053 Zvolen, Slovakia; skvareninova@is.tuzvo.sk \\ * Correspondence: miklosmiso@gmail.com (M.M.); skvarenina@tuzvo.sk (J.S.); Tel.: +421-455-206-209 (J.S.)
}

Received: 17 August 2020; Accepted: 15 December 2020; Published: 18 December 2020

\begin{abstract}
Climate change affects snowpack properties indirectly through the greater need for artificial snow production for ski centers. The seasonal snowpacks at five ski centers in Central Slovakia were examined over the course of three winter seasons to identify and compare the seasonal development and inter-seasonal and spatial variability of depth average snow density of ski piste snow and uncompacted natural snow. The spatial variability in the ski piste snow density was analyzed in relation to the snow depth and snow lances at the Košútka ski center using GIS. A special snow tube for high-density snowpack sampling was developed (named the MM snow tube) and tested against the commonly used VS-43 snow tube. Measurements showed that the MM snow tube was constructed appropriately and had comparable precision. Significant differences in mean snow density were identified for the studied snow types. The similar rates of increase for the densities of the ski piste snow and uncompacted natural snow suggested that the key density differences stem from the artificial (machine-made) versus natural snow versus processes after and not densification due to snow grooming machines and skiers, which was relevant only for ski piste snow. The ski piste snow density increased on slope with decreasing snow depth $\left(18 \mathrm{~kg} / \mathrm{m}^{3}\right.$ per each $\left.10 \mathrm{~cm}\right)$, while snow depth decreased $2 \mathrm{~cm}$ per each meter from the center of snow lances. Mean three seasons maximal measured density of ski piste snow was $917 \pm 58 \mathrm{~kg} / \mathrm{m}^{3}$ the density of ice. This study increases the understanding of the snowpack development processes in a manipulated mountainous environment through examinations of temporal and spatial variability in snow densities and an investigation into the development of natural and ski piste snow densities over the winter season.
\end{abstract}

Keywords: snow density; snow tube; technology; artificial snow; ski slope; piste; VS-43; snow depth; snow lances; water balance

\section{Introduction}

A seasonal snow cover that is deposited and melts annually is a major component of regional and global hydrologic balances due to its effects on energy and moisture budgets [1,2]. To calculate snowmelt, a major source of water from mountainous areas in temperate zones [3], the development of snow water equivalent (SWE) over the winter season shall be monitored [4]. The SWE is possible to identify from the extracted snow core directly by a calibrated scale or indirectly by calculation from the snow depth and density (weight) measurements [5]. However, both methods are time consuming due to snow core extraction and weighing. Mathematical models of snow density development over the winter season and/or models of relationship between snow depth and density could potentially 
save lot of time and effort by allowing SWE calculations to be made on the basis of snow depth measurements and estimated snow density only [6,7]. Such models have not yet been developed for a ski piste snowpack; thus, doing so is a goal of this study. For this purpose, a series of snow density measurements must be performed via snow core extraction and weight measurements. To extract a gravimetric snow core from a snowpack, a snow tube is used [8]. The snow tube was first popularized by Church [5,9] and is still utilized by snow surveyors in forested, remote, or hilly watersheds [10]. Manual measurements utilizing a snow tube frequently underestimate depth-average snow density and the SWE of a snowpack due to sampling difficulties associated with the high density of ground ice [11]. It is impossible to extract an ice sample or sample through an ice layer when a conventional snow tube is used. Keller et al. [12], when dealing with impact of ski-slope grooming on the snowpack and soil properties, mention that after mid-December, the snow on the ski slope they were investigating was too hard for manual snow-density measurements to be obtained with a snow tube designed for uncompacted natural snow. Therefore, Rixen et al. [13] sampled such snow with a motor-driven SIPRE corer [14] to compare the physical properties of artificial and natural snow; however, this approach is not practical due to construction and operation costs. In addition, motor-driven devices for snow core extraction are much more complicated to construct and operate than snow tubes. However, snow tubes suitable for a groomed ski piste snowpack or a natural snowpack of high density have not yet been developed (an aim of the present paper). Another approach is to use a PICO coring auger [15] designed for ice sampling for the manual extraction of snow samples from a high-density snowpack [16]. The snow density of a ski piste snowpack is essential for the assessment of the environmental impacts of ski piste management [17], for the calculation of the SWE and water balance [18], for defining the snow type [19], and mainly for a quality assessment of the ski piste snowpack for winter sports [20]. Snow metamorphoses, depending on the meteorological conditions, the physical properties of the overlying snow, time on the ground, and mechanical disturbances, can change the snowpack's density [21]. Compared to natural snow cover, the snow on the ski pistes is increased mechanically via snow grooming machines and artificial snow [22]. Federolf et al. [23] observed that groomed ski slopes covered by natural snow have densities ranging from 330 to $660 \mathrm{~kg} / \mathrm{m}^{3}$, while Rixen et al. [24] identified a similar density range for freshly-produced artificial snow. A whole season's worth of systematic measurements of the depth-average density of a groomed ski piste snowpack with artificial snow added has not yet been published (another aim of the present paper).

Ongoing and future changes in forest composition and climatic conditions have and will modify the seasonal distribution of both precipitation and runoff in the pilot region [25,26]. As a consequence, the operability of Central Slovakian ski slopes up until $1000 \mathrm{~m}$ a.s.l. is highly dependent on snow production, as shown in our previous study [27]. Winter precipitation and water availability during the skiing season is decreasing, in general $[28,29]$. Therefore, a high volume of artificial snow is produced at the beginning of each season for the groomed ski pistes of Central Slovakia. However, the snow densities and microstructures, which are used to define snow types [19], of natural and artificial snow differ markedly, both in the case of freshly fallen/produced snow and in the case of older, metamorphic snow on the ground [30,31]. The following snow types were examined in the present article: (i) new natural snow (max. 2-day-old snowpack), (ii) new artificial snow (max. 2-day-old machine-made snowpack), (iii) uncompacted natural snow, and iv) ski piste snow. The main goal of this study was to identify models of temporal and spatial development of ski piste snow density that could allow density estimation to be made on the basis of the term in winter season and / or snow depth measurements. The spatial development of ski piste snow density was analyzed only in one ski center at the end of the winter season; thus, this model can be generalized only for the late snow ablation period. To reach the main goal and fill gaps in the research on the groomed and snowed ski piste snowpack described above, the following sub-objectives were set: 
A. Snow tube construction:

- Design and construct a snow tube suitable for depth-average snow density measurements of a groomed ski piste snowpack with artificial snow added.

- Identify the precision of the designed snow tube on ski piste and off-piste sites through comparison of snow density measurements with commonly used VS-43 snow tube.

B. Density of snow at five ski centers:

- Identify and compare the mean, minimal, and maximal densities of ski piste snowpack with uncompacted natural snowpack on a seasonal and monthly scale and do the same for new artificial snow and new natural snow measured at the beginning of the winter season.

- Identify and compare the seasonal and inter-seasonal course densities and variabilities in the densities of ski piste and uncompacted natural snow and describe them with linear mathematical models if applicable to identify slope of increase over the season.

C. Snow density versus snow depth relationship on the example of Košútka ski center:

- Identify the spatial distribution of the snow depth and the spatial variability of the snow density in the ski piste area and analyze the correlations between these two variables and the positions of fixed snow-making lances at the end of the winter season.

\section{Materials and Methods}

\subsection{Study Sites}

The study was conducted at five ski centers located in Central Slovakia (Figure 1). The elevation of the ski slopes varied from 510 to $1402 \mathrm{~m}$ a.s.l., while all study sites at the ski centers were located at elevations lower than $1000 \mathrm{~m}$ a.s.l. (Figure 1). According to the geomorphological classification [32,33], all the ski centers are located in the Inner Western Carpathian sub-province. According to Slovakia's climate classifications [34], the higher ski resorts (Krahule and Donovaly) belong to subregion C1 (moderately cool), while the lower resorts (Košútka and Jasenská) are included in the climate subregions M7 (moderately warm, very humid, highlands) and M6 (moderately warm, humid, highlands), respectively. Based on the annual temperature amplitudes, the lower research plots belong to the transitional maritime climate to moderately continental climate, while, for the higher ski resorts, the temperature amplitude decreases and the oceanity of the climate increases [35]. Further detailed characteristics of the resorts' climatic and natural conditions are given in Table 1, which has been processed according to the Climate Atlas of Slovakia [36] and Hrvol' et al. [37]. As we can see from the Table 1, the number of days with snow cover and the average snow depth increase with increasing altitude [38-40]. The potential natural vegetation is described in terms of Skvarenina et al. [41].
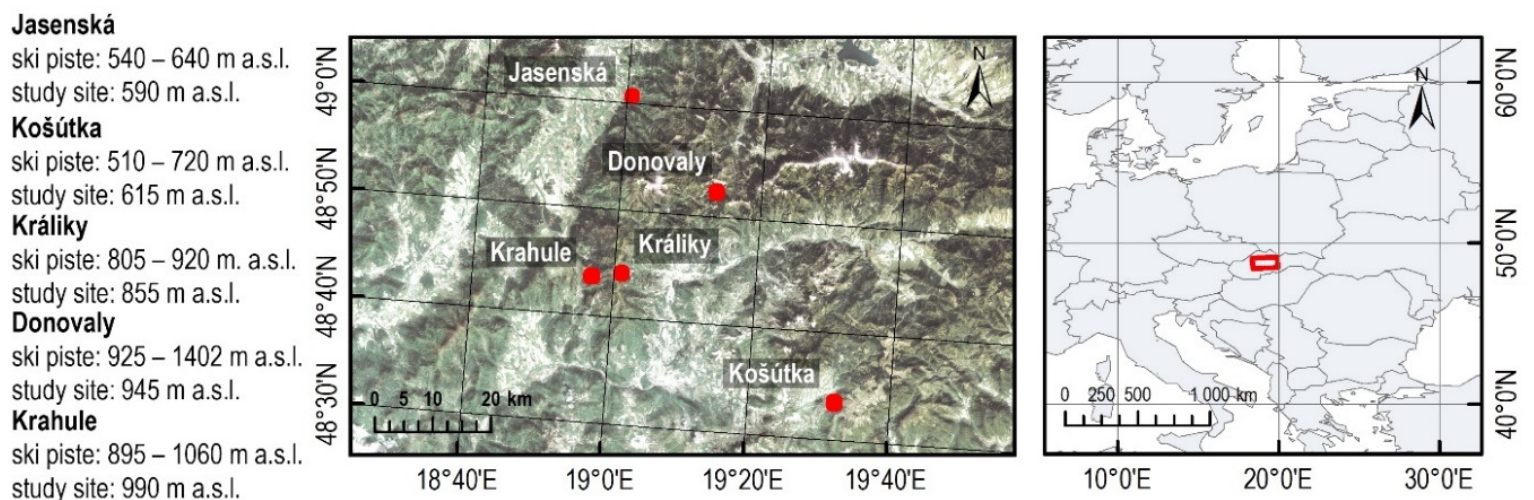

Figure 1. Ski centers' elevations and locations in Central Slovakia and Central Europe. 
Table 1. The basic environmental characteristics of five ski centers in Central Slovakia at which the snow density was examined, according to the Climate Atlas of Slovakia [36] where data from 1961 to 2010 were processed.

\begin{tabular}{|c|c|c|c|c|c|}
\hline & Jasenská & Košútka & Králiky & Krahule & Donovaly \\
\hline $\begin{array}{l}\text { Altitude } \\
\text { (m a. s. 1.) }\end{array}$ & 590 & 615 & 855 & 990 & 945 \\
\hline GPS & $\begin{array}{l}\mathrm{N} 49.00976^{\circ} \\
\mathrm{E} 19.00959^{\circ}\end{array}$ & $\begin{array}{l}\mathrm{N} 48.55909^{\circ} \\
\mathrm{E} 19.53484^{\circ}\end{array}$ & $\begin{array}{l}\mathrm{N} 48.73626^{\circ} \\
\mathrm{E} 19.01706^{\circ}\end{array}$ & $\begin{array}{l}\mathrm{N} 48.72824^{\circ} \\
\mathrm{E} 18.94727^{\circ}\end{array}$ & $\begin{array}{l}\mathrm{N} 48.87313^{\circ} \\
\mathrm{E} 19.22425^{\circ}\end{array}$ \\
\hline Geomorphological units & Vel'ká Fatra & $\begin{array}{l}\text { Vepor } \\
\text { Mountains }\end{array}$ & $\begin{array}{l}\text { Kremnica } \\
\text { Mountains }\end{array}$ & $\begin{array}{l}\text { Kremnica } \\
\text { Mountains }\end{array}$ & $\begin{array}{l}\text { Staré Hory } \\
\text { Mountains }\end{array}$ \\
\hline Aspect & $\mathrm{N}$ & NW & $\mathrm{NE}$ & SW & $\mathrm{N}$ \\
\hline $\begin{array}{l}\text { Average annual air } \\
\text { temperature }\left({ }^{\circ} \mathrm{C}\right)\end{array}$ & 6.9 & 6.7 & 5.2 & 4.8 & 4.5 \\
\hline $\begin{array}{l}\text { Average winter air } \\
\text { temperature }\left({ }^{\circ} \mathrm{C}\right)\end{array}$ & -2.8 & -3.1 & -3.9 & -4.1 & -4.4 \\
\hline $\begin{array}{l}\text { Average annual } \\
\text { precipitation total }(\mathrm{mm})\end{array}$ & 850 & 755 & 1080 & 1025 & 1180 \\
\hline $\begin{array}{l}\text { Average winter } \\
\text { precipitation total }(\mathrm{mm})\end{array}$ & 160 & 130 & 240 & 220 & 250 \\
\hline $\begin{array}{l}\text { Average number of day } \\
\text { with snow cover }(\geq 10 \mathrm{~cm})\end{array}$ & 55 & 48 & 70 & 68 & 87 \\
\hline $\begin{array}{l}\text { Average number of day } \\
\text { with snow cover }(\geq 20 \mathrm{~cm})\end{array}$ & 35 & 27 & 45 & 47 & 66 \\
\hline $\begin{array}{l}\text { Average number of day } \\
\text { with snow cover }(\geq 50 \mathrm{~cm})\end{array}$ & 9 & 6 & 10 & 12 & 27 \\
\hline $\begin{array}{l}\text { Average snow cover depth } \\
(\mathrm{cm})\end{array}$ & 40 & 37 & 53 & 56 & 65 \\
\hline Climatic sub region & M7 & M6 & $\mathrm{C} 1$ & $\mathrm{C} 1$ & $\mathrm{C} 1$ \\
\hline $\begin{array}{l}\text { Watercourse/ Drainage } \\
\text { basin }\end{array}$ & $\begin{array}{l}\text { Beliansky } \\
\text { potok/Váh }\end{array}$ & Slanec/Hron & $\begin{array}{c}\text { Tajovský } \\
\text { potok/Hron }\end{array}$ & $\begin{array}{l}\text { Krahulský } \\
\text { potok/Hron }\end{array}$ & Korytnica/Váh \\
\hline $\begin{array}{l}\text { Potential natural } \\
\text { vegetation }\end{array}$ & $\begin{array}{l}\text { 3th } \\
\text { oak-beech } \\
\text { stage }\end{array}$ & $\begin{array}{l}\text { 4th beech } \\
\text { stage }\end{array}$ & $\begin{array}{l}\text { 5th fir-beech } \\
\text { stage }\end{array}$ & $\begin{array}{l}\text { 5th fir-beech } \\
\text { stage }\end{array}$ & $\begin{array}{c}\text { 6th } \\
\text { spruce-beech-fir } \\
\text { stage }\end{array}$ \\
\hline
\end{tabular}

\subsection{Snow Tube}

Snow tubes are used to extract gravimetric samples of snow (snow cores) in order to measure the depth-averaged snow density and SWE [8]. The snow tube used on the groomed ski pistes with high-density snow was developed (Table 2, see Figure $2 b$ in Section 3.1) and named the MM snow tube due to the highly used man-made (artificial) snow on the groomed ski slopes and the initials of its designer (first author of this article). To extract the snow core with the designed tube, it was necessary to use a heavy hammer (approx. $3.5 \mathrm{~kg}$ ). Before removing the tube from the snowpack for weighing, the snow core had to be pressed inside to increase sample adhesiveness. To make it easier to pull it from the snowpack and taking into consideration the possible use of a hanging weight, a stainless-steel hose clamp with hanging rope was placed on the top of the tube. After weighing, the snow core was pushed out of the tube with an aluminum rod with a penny washer $(\mathrm{M} 8 \times 30 \mathrm{~mm})$ on one side.

Table 2. Main characteristics of the snow tubes used in this study.

\begin{tabular}{|c|c|c|c|c|c|c|}
\hline Snow Tube & Cap & Material & Length (mm) & $\begin{array}{l}\text { Weight (Cap) } \\
\text { (kg) }\end{array}$ & Inner $\varnothing(\mathrm{mm})$ & $\begin{array}{c}\text { Sampling } \\
\text { Time (min.) * }\end{array}$ \\
\hline $\mathrm{MM}$ & + & $\begin{array}{l}\text { Stainless } \\
\text { Steel }\end{array}$ & 800 & $4.18(0.76)$ & 40 & $4 \pm 2$ \\
\hline VS-43 & + & Aluminum & 600 & $1.25(0.17)$ & 84 & $15 \pm 5$ \\
\hline
\end{tabular}

* Average sampling time of the 30 paired measurements (mean \pm standard deviation). 
(a)
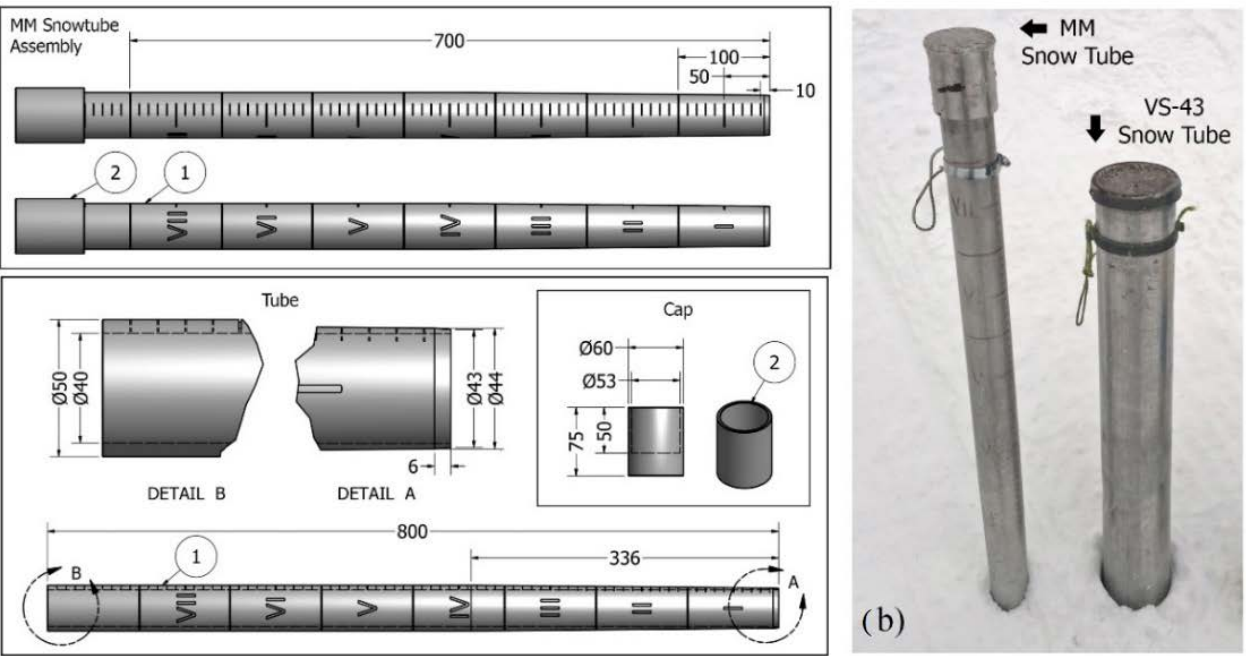

Figure 2. (a) Assembly of the MM snow tube, which consisted of a tube and cup (dimensions in $\mathrm{mm}$ );

(b) Commonly used VS-43 snow tube in comparison with the designed tube.

To assess precision and reliability of the MM tube on the groomed ski piste, 30 paired measurements were performed in January 2017 at Králiky. A snow tube that is popular in Europe and Russia named the VS-43 was used for comparison (Table 2) [42]. The assembly of the VS-43 snow tube with its original mechanical scales is illustrated in Figure A1 in Appendix A. The VS-43 snow tube was destroyed during the 30 paired measurements, because the aluminum did not stand up to the hammering. The precision of the new snow tube was assessed on uncompacted natural snow, as well. In this case, 30 paired measurements were taken at Donovaly in March 2017.

\subsection{Snow Density}

Depth average density of the four following snow types were identified at the five ski centres (Jasenská, Košútka, Králiky, Krahule, Donovaly) across three winter seasons from 2014/15 to 2016/17: (i) new artificial snow (max. two-day-old machine-made snow), (ii) new natural snow (max. two-day-old snowpack), (iii) ski piste snow (groomed snow with artificial snow added), and (iv) uncompacted natural snow on off-piste sites. The densities of all four types of snow were identified via series of five measurements. If natural snow occurred on the off-piste site, then the measurements of the ski piste and natural snowpacks were always paired. Measurements began with the first occurrence of natural snow for the season and carried on over the course of irregular time intervals, which were 17 days long, on average. The density measurements for the ski piste and natural snowpacks were identified on the horizontal transect that intersected groomed ski piste and adjacent off-piste sites with uncompacted natural snow. A series of five measurements were made at groomed ski piste and off-piste sites that were paired according to site properties, such as elevation, slope, aspect, curvature of relief, and obscuration. The densities of uncompacted and new natural snow were sampled with the VS-43 snow tube, while new artificial snow and ski piste snow were sampled with the MM snow tube.

The samples were compared via paired or unpaired Student's $t$-tests at an alpha level of 0.05 and $n-1$ degrees of freedom. In each case, the proper test was chosen according to the assumptions required for the samples. Both tests assumed that the variables were normally distributed, the observations were sampled independently, and the variables were from two related groups or matched pairs; the unpaired $t$-test assumed that the variables were from two independent groups with the same variance. The type of $t$-test used is identified when the results of a case are discussed. Mean values mentioned in results are accompanied with the standard deviation and number of samples $(\mathrm{N} / n)$ used for calculation. The total number of measured samples $(\mathrm{N})$ or number of mean values $(n)$ can be found. 


\subsection{Snow Density Versus Snow Depth}

At the end of the winter season on 15 March 2015, when the natural snow on the adjacent off-piste sites has melted away, the snow depth and density of the ski piste snowpack were measured along the whole ski piste at Košútka to analyze the correlations between the snow density and depth variables and the distance from the snow lances. The snow depth was measured at 96 sampling points, while the snow density was measured at 72 of these points. To analyze the spatial distribution of the snow and spatial variability of the snow density, the snow depth, and density raster layers were interpolated from the point measurements in ArcGIS 10.3.1. The raster layers, which consist of matrices of cells organized into rows and columns, where each cell contains a value representing information, such as snow depth or density, as in this paper, were created to provide pictures of these real-world phenomena. The interpolation spline technique was used to create raster layers with $1 \times 1 \mathrm{~m}$ cell sizes. The spline technique was chosen, because it guarantees that the resulting surface will pass through the data points exactly, making it ideal for generating gently varying surfaces, such as snowpack surfaces or elevation. The correlations between the snow depth and density raster layers were computed with the Band Collection Statistics tool in ArcGIS 10.3.1. Concentric circles around snow lances were used to analyze the relationship between the snow depth and density [16]. The mean snow density and depth were calculated on concentric circles of radius $\mathrm{R}=5,7.5,10 \ldots 30 \mathrm{~m}$ around each of the 17 snow lances. The maximum radius of $30 \mathrm{~m}$ was equal to the maximum distance that water/ice particles emitted from the used snow lances in Košútka ski centre could travel without wind support. This distance depends on the type and technology of used snowmaking machines.

\section{Results}

\subsection{Snow Tube}

A $800 \mathrm{~mm}$-long snow tube with a 50-mm outside diameter and 5-mm-thick walls that began tapering $336 \mathrm{~mm}$ from the cutting end was constructed (Figure 2a). The wall thickness of the sharpened cutting end was $1.5 \mathrm{~mm}$. The weight of the tube without its cap was $4.2 \mathrm{~kg}$, while the $100 \mathrm{~mm}$ of the tube used for construction weighed $0.6 \mathrm{~kg}$. An essential part of the tube was its removable cap. EN 1.4310 (X10CrNi18-8) stainless steel was selected as the construction material due to its hardness and corrosion resistance. The measurement scale was engraved on the outside wall of the tube that was used to measure the snow depth or identify how deep the tube had penetrated.

The paired $t$-test showed no significant difference $(p$-value $=0.23)$ between the samples collected by the MM tube and the commonly used VS-43 snow tube (Figure 3). The average difference between the observations in pairs was $22.2 \pm 18.1 \mathrm{~kg} / \mathrm{m}^{3}$, while the MM tube underestimated the snow density compared to the VS- 43 tube by about $2.1 \pm 3.9 \%$, on average. The VS-43 snow tube (Figure $2 b$ ) has a design that is similar to that of the MM tube, but, when it was used on a ski slope, the following disadvantages were noted: (i) long sampling time, (ii) it had difficulty penetrating the snowpack, (iii) it was hard to remove from the snowpack (the sampler usually stuck in the snowpack due to the bigger diameter of the cutting end compared to the diameter of the tube), and (iv) inadequate construction (after a few samples, the sampler was deformed by the hammering). The tendency of the MM snow tube to underestimate the snow density was detected for natural snow as well, and it underestimated the density by about $6.9 \pm 2.9 \%$ (Figure 3 ). In the case of uncompacted natural snow, the paired $t$-test detected a difference between the samples taken by the two snow tubes. Therefore, the MM tube is not recommended for use mainly when the snowpack is shallow and has a low density (new natural snow), possibly due to low sample weights (small tube diameter), which are difficult to detect precisely in the field with a hanging weight. 


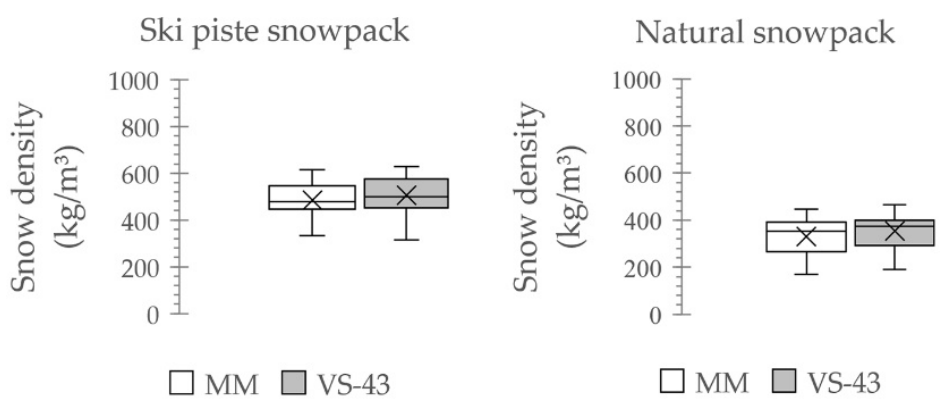

Figure 3. Comparison of 30 paired measurements of the snow densities of ski piste and uncompacted natural snow measured by designed MM snow tube versus the VS-43 snow tube.

\subsection{Snow Density}

The mean densities of the types of snow were calculated for three seasons with data from the five ski centres. These densities indicated that the mean density of new artificial snow was 2.3 times higher than the mean density of new natural snow $\left(409.6 \pm 66.2 \mathrm{~kg} / \mathrm{m}^{3}\right.$ versus $175.3 \pm 71.6 \mathrm{~kg} / \mathrm{m}^{3} ; \mathrm{N}=209$ versus 199 samples) and that the mean density of ski piste snow was 2.5 times higher than the density of uncompacted natural snow on the off-piste sites $\left(595.9 \pm 101.0 \mathrm{~kg} / \mathrm{m}^{3}\right.$ versus $238.5 \pm 95.3 \mathrm{~kg} / \mathrm{m}^{3}$; $\mathrm{N}=722$ versus 400 samples; Figure 4). The following is a list of snow types according to their mean densities (in descending order): ski piste snow (mixture of natural and artificial snow), new artificial snow (max. two-day-old machine-made snow), uncompacted natural snow, and new natural snow. The data over the three seasons showed significant differences (unpaired $t$-test: $p<0.5$ ) across all four studied snow types. The ski piste snow had greater seasonal variability than the uncompacted natural snow (Figure 4). Mean difference between the maximal and minimal density (except for outliers; Figure $4 \mathrm{~b}$ ) identified in each of five ski centers over the three winter seasons for the types of snow were as follows: (i) $420 \pm 87 \mathrm{~kg} / \mathrm{m}^{3}$ for ski piste snow, (ii) $328 \pm 80 \mathrm{~kg} / \mathrm{m}^{3}$ for uncompacted natural snow, (iii) $273 \pm 66 \mathrm{~kg} / \mathrm{m}^{3}$ for new artificial snow, and (iv) $211 \pm 59 \mathrm{~kg} / \mathrm{m}^{3}$ for new natural snow. A paired comparison of the mean differences between the maximal and minimal densities of snow (excluding outliers) at the ski centers showed no significant difference (paired $t$-test: $p>0.5$ ) between ski piste and uncompacted natural snow (comparable differences, not maximal and minimal values) but showed a significant difference (paired $t$-test: $p<0.5$ ) between new artificial and new natural snow. Outliers were identified mainly for ski piste snow at all five ski centers. The mean density of the ski piste snowpack calculated from the peak outliers identified at the ski centers was $917 \pm 58 \mathrm{~kg} / \mathrm{m}^{3}(n=5$; peak outlier is highest measured value displyed in Figure 4a), which is the density of ice. The peak outliers of ski piste snow were not significantly different (paired $t$-test: $p>0.5$ ) from the density of ice.

The highest three seasons mean density of new artificial snow $\left(435.8 \pm 55.7 \mathrm{~kg} / \mathrm{m}^{3}, \mathrm{~N}=34\right.$ samples $)$ and ski piste snow $\left(621.1 \pm 111.3 \mathrm{~kg} / \mathrm{m}^{3}, \mathrm{~N}=139\right.$ samples) were identified at a low-elevation ski center, namely, Košútka (Figure 4). The lowest and highest three seasons mean densities of new natural snow were identified at high-elevation ski centers, namely, Krahule $\left(134.6 \pm 37.4 \mathrm{~kg} / \mathrm{m}^{3} ; \mathrm{N}=30\right.$ samples) and Donovaly $\left(210.4 \pm 68.2 \mathrm{~kg} / \mathrm{m}^{3}, \mathrm{~N}=49\right.$ samples), respectively. The mean density of uncompacted natural snow was lowest at Košútka $\left(181.1 \pm 88.9 \mathrm{~kg} / \mathrm{m}^{3}, \mathrm{~N}=38\right.$ samples $)$ and highest at Donovaly $\left(270.0 \pm 96.6 \mathrm{~kg} / \mathrm{m}^{3}, \mathrm{~N}=103\right.$ samples $)$.

The mean density of ski piste snow in December calculated from all measured data was $538.9 \pm 135.2 \mathrm{~kg} / \mathrm{m}^{3}$, while its increase per month was $13.2 \mathrm{~kg} / \mathrm{m}^{3}$ (Figure 5). The mean monthly density of ski piste snow had a tendency to increase over the whole winter season, except at the end of the season in April, when the mean monthly density was equal to the mean density in March. The mean density of uncompacted natural snow in December was $190.8 \pm 116.5 \mathrm{~kg} / \mathrm{m}^{3}$, while its increase per month was $28.2 \mathrm{~kg} / \mathrm{m}^{3}$. The mean monthly density of uncompacted natural snow had a tendency to increase over the whole season from December to April, except for the month of March. The mean monthly densities of ski piste snow and uncompacted natural snow were significantly 
different (paired $t$-test: $p<0.5$ ). The average seasonal difference between the mean monthly densities of ski piste snow and uncompacted natural snow (displayed in Figure 5) was $324.6 \pm 46.0 \mathrm{~kg} / \mathrm{m}^{3}$. The low standard deviation of this difference the mean monthly densities of both types of snow showed comparable increases. The highest difference in the mean monthly densities of ski piste snow and uncompacted natural snow was found in March $\left(372 \mathrm{~kg} / \mathrm{m}^{3}\right)$, which also had the highest maximal $\left(980 \mathrm{~kg} / \mathrm{m}^{3}\right)$ and mean $\left(635 \mathrm{~kg} / \mathrm{m}^{3}\right)$ densities of ski piste snowpack (Figure 5). The mean monthly density of uncompacted natural snow exceeded the mean monthly density of ski piste snow in January and April only by about 60 and $35 \mathrm{~kg} / \mathrm{m}^{3}$, respectively. In contrast, the minimal mean monthly density of ski piste snow never dropped below the mean monthly density of uncompacted natural snow.
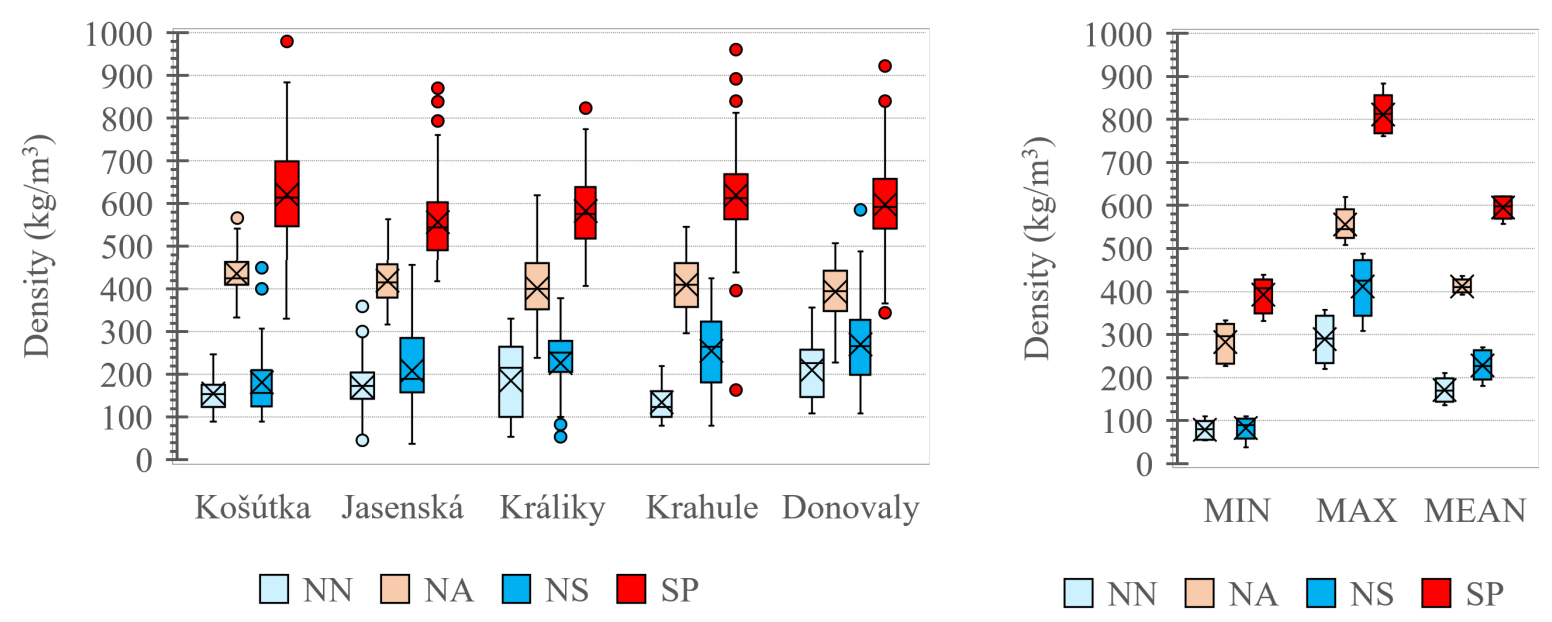

Figure 4. (a) Comparison of the data for three seasons with regard to the snow density of new natural snow (NN), new artificial snow (NA), uncompacted natural snow (NS), and ski piste snow (SP) for the five ski centers. The lowest number of measured samples $(\mathrm{N}=30)$ was in the case of NA in Kraíliky and NN in Krahule. Description of boxplot: cross = mean, horizontal line in the box $=$ median, box $=50 \%$ of values, box with whiskers $=99 \%$ of values, points $=$ outliers. $($ b) Boxplots of the minimal, maximal, and mean density identified in each of five ski centers (excluding outliers) over the three winter seasons for four snow types $(n=5)$.

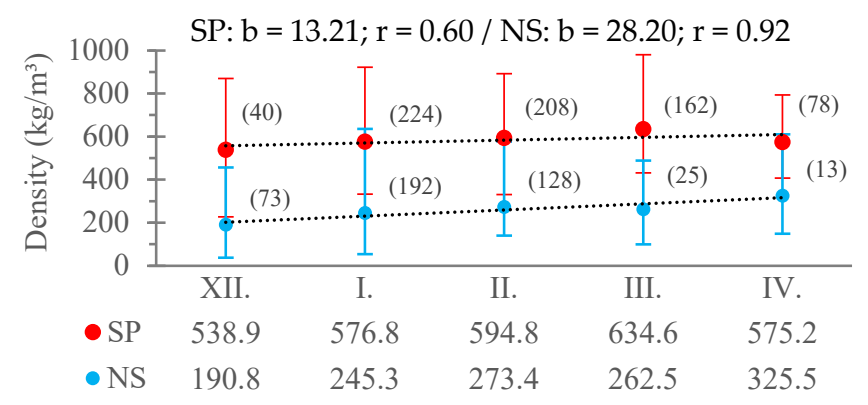

Figure 5. Increases in the mean monthly density of ski piste snow (SP) and uncompacted natural snow (NS) over the winter season (mean $\pm \mathrm{min} / \mathrm{max}$ ). The means from three seasons calculated from all data measured at the five ski centers are displayed. $\mathrm{b}=$ slope of regression line, $\mathrm{r}=$ correlation coefficient, $(\mathrm{x})=$ the total number of samples.

The densities of the ski piste snow and uncompacted natural snow showed an increasing seasonal trend and inter-seasonal variability in all three winter seasons across all five ski centers, except for seasons with shortages of natural snow (Figure 6). The slopes of the regression models in Figure 6 indicate no significant difference between ski piste snow and uncompacted natural snow when compared with the paired $t$-test $(p<0.5)$. The mean values of these slopes were comparable when calculated from data with moderate or higher correlations ( $r \geq 50$; Figure 6). While the increase in the density of the ski piste snow over a season was $1.9 \pm 1.2 \mathrm{~kg} / \mathrm{m}^{3}$ per day (mean \pm standard deviation), on 
average, the increase in the density of uncompacted natural snow over the season was $2.3 \pm 1.3 \mathrm{~kg} / \mathrm{m}^{3}$ per day, on average. The similar rates of increase for the densities of the two snow types suggest that the key density differences stem from the artificial (machine-made) versus natural snow versus processes after and not densification due to snow grooming machines and skiers, which was relevant only for ski piste snow. The difference (paired $t$-test: $p<0.5$ ) between the linear models for the ski piste snow and natural snow was in the starting density. At the beginning of the winter season, the density of the ski piste snow was $434.5 \pm 63.9 \mathrm{~kg} / \mathrm{m}^{3}$, while the density of the uncompacted natural snow was $169.5 \pm 63.9 \mathrm{~kg} / \mathrm{m}^{3}$, on average (mean values for three seasons calculated from the means of first surveys of the seasons; $n=15$ ). Consistent relationships between time and mean density are illustrated by the trend lines and supported by the correlation coefficients, which are high in most of the seasons, although the correlation coefficients may not be reliable measures given the few data points (Figure 6). The correlation between these variables was reduced by the large outlier values, mainly in case of the ski piste snow. The outliers, for the ski piste snow were identified in the following surveys: 27 January 2015 (Králiky); 18 January 2015 (Krahule); and 21 December 2017 (Donovaly). When the density of the ski piste snow increased to outliers in these surveys, the density of natural snow did not follow same pattern. Therefore, such exceptional growth in the ski piste snow density should be connected with management activities regarding the ski piste snowpack (snowmaking, grooming, and so on).

The identification of occurrences or durations of these snowpacks was not the aim of the present paper; however, in most of the paired measurements, the measurements for natural snow were missing approximately from the middle of February until the end of the winter season (Figure 6). The reason for these missing values was the absence of natural snow. Therefore, the density of ski piste snow increased for a longer period and reached higher mean seasonal values compared to the density of natural snow, which melted earlier.

\subsection{Snow Density Versus Snow Depth on the Ski Piste of Košútka Ski Center}

The snow depth and density were measured manually on 5 March 2015, from 72 sampling points at Košútka, and a moderately strong negative linear correlation was calculated with the data (Figure 7). According to this correlation, the density increased $18 \mathrm{~kg} / \mathrm{m}^{3}$ per $10 \mathrm{~cm}$ of decreasing snow depth. The average deviation of this linear model was calculated as $\pm 72 \mathrm{~kg} / \mathrm{m}^{3}$ and represents the standard error of estimation (RMSE with two degrees of freedom). The snow density ranged from 457 to $969 \mathrm{~kg} / \mathrm{m}^{3}$ (Figure 7), with a mean of $632 \pm 85 \mathrm{~kg} / \mathrm{m}^{3}$ (mean \pm standard deviation). The minimal average density was found at a maximal depth of $135 \mathrm{~cm}$, while the maximal density was associated with nearly the minimal depth of snow $\left(969 \mathrm{~kg} / \mathrm{m}^{3}\right.$ for $13 \mathrm{~cm}$ versus $640 \mathrm{~kg} / \mathrm{m}^{3}$ for $5 \mathrm{~cm}$ ). The Snow profile was saturated with meltwater during measurements; thus, the maximal density of the snow was higher than the density of ice. 

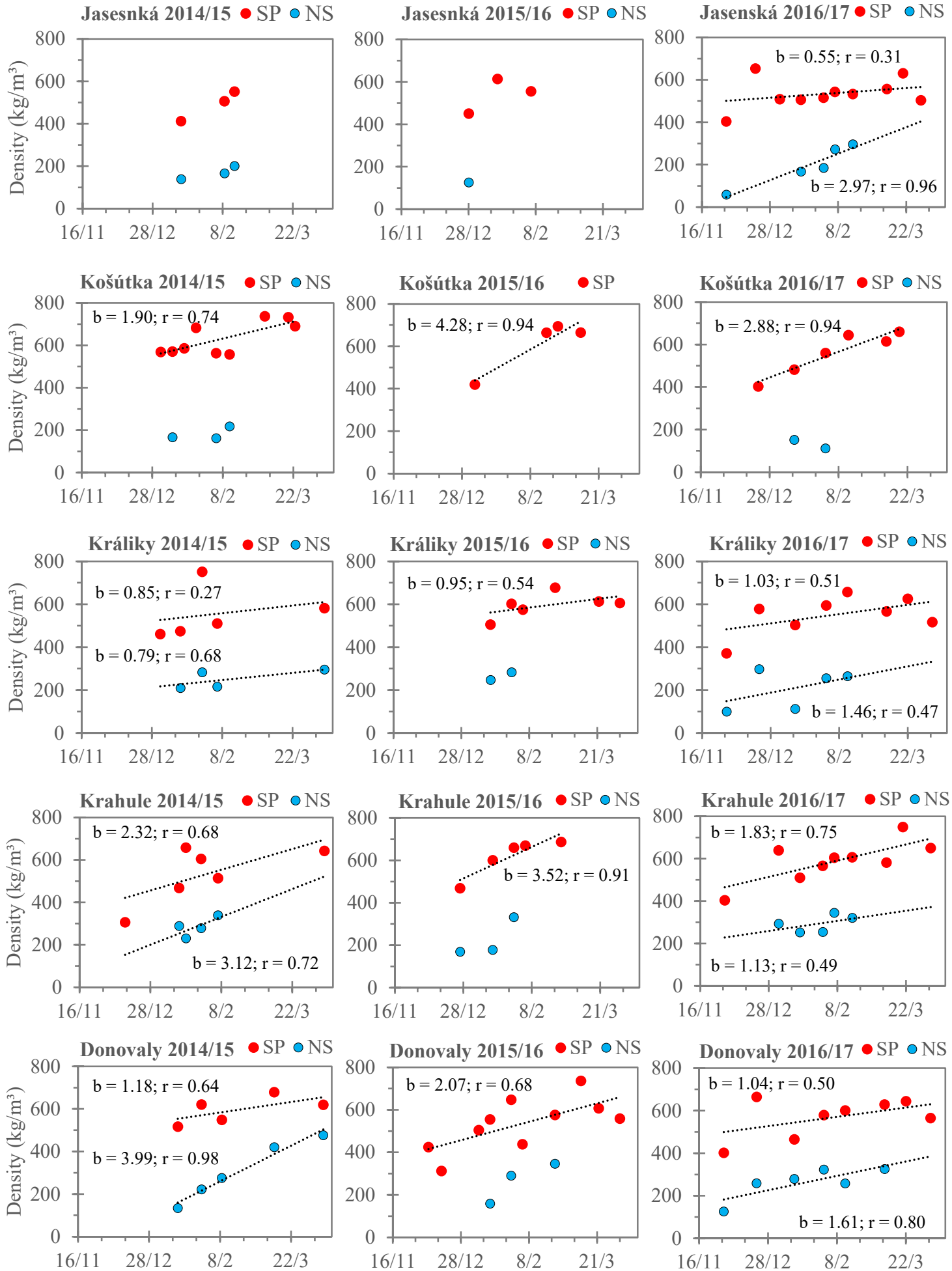

Figure 6. The mean densities of ski piste snow (SP) and uncompacted natural snow (NS) and their increases over three winter seasons (from 2014/15 to 2016/17) at five ski centers. The mean density was calculated from at least five measurements/samples. The slopes of the regression lines (b) indicate the increase in the mean densities of the snow per day, and the correlation coefficients ( $r$ ) indicates weak $(+30)$, moderate $(+50)$, or strong $(+70)$ linear models. The snow density measurements for SP and NS were paired. The absence of measurements for NS means the absence of natural snowpack on these dates. 


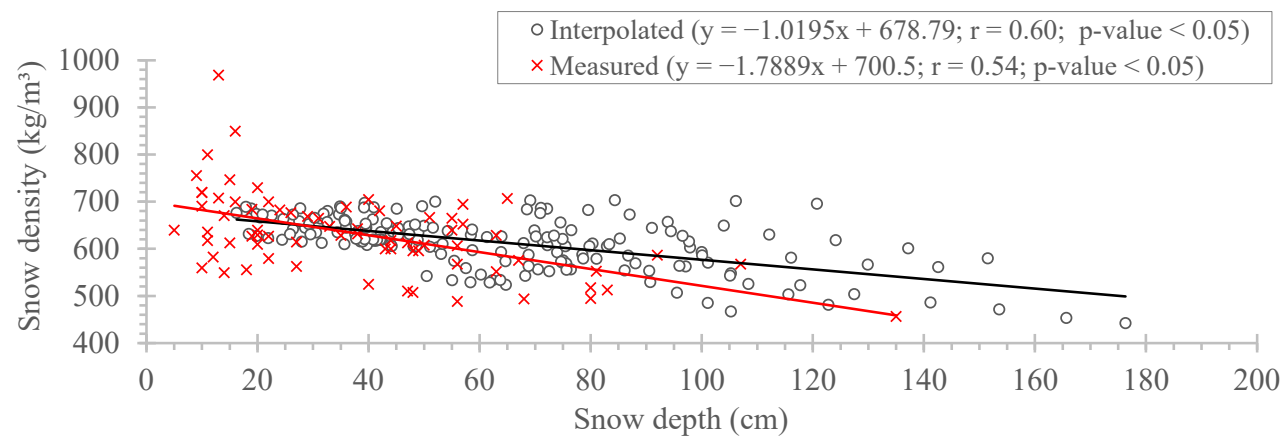

Figure 7. Correlation between measured values on 5 March 2015, (red line) and correlation between the mean depth and density of the interpolated ski piste snowpack on the basis of 181 concentric circles around snow lances. Correlation coefficients ( $\mathrm{r}$ ) and $p$-values from analysis of variance (ANOVA) are displayed.

The snow depth and snow density raster layer were interpolated from the 72 sampling points (Figure 8) to analyze the spatial distribution of these variables on the ski piste. Both snow density and depth showed similar, but reverse, geometric patterns along the entire ski piste, as indicated by the negative correlation. The correlation between these two raster layers was lower than that between the 72 paired, manually measured values $(r=0.31$ versus $r=0.54)$. Intensive snow making at the ski center resulted in the occurrence of snow piles with maximum measured and interpolated depths of 198 and $211 \mathrm{~cm}$, respectively (Figure 8). Each of the 17 snow lances produced a different volume of snow during the season; thus, the depths of the snow piles differed significantly. According to the interpolated snow depth raster (Figure 8), the centers of snow piles were located $12.5 \pm 4.9 \mathrm{~m}$ from the closest snow lance, on average. These centers were situated down the slope, except for first two snow lances at the foot of the slope. The average snow depth and snow density in the centers of the snow piles were $110 \pm 52 \mathrm{~cm}$ and $573 \pm 70 \mathrm{~kg} / \mathrm{m}^{3}$, respectively. Strength and slope of correlation between the mean depth and density of the interpolated values on the basis of 181 concentric circles around snow lances was comparable as correlation between measured values (Figure 7). The mean snow depth and density calculated on such circles decreased $2 \mathrm{~cm}$ and $3 \mathrm{~kg} / \mathrm{m}^{3}$ per each meter from the center of snow lance, respectively. These ratios were identified from slopes of the linear relationships between a series of raddi around snowmaking lances $(5,7.5,10 \ldots 30 \mathrm{~m})$ and (i) snow depth $(\mathrm{y}=-1.9648 \mathrm{x}+99.019$; $\mathrm{r}=0.97 ; n=181)$, and (ii) depth average snow density $(\mathrm{y}=2.8164 \mathrm{x}+563.41 ; \mathrm{r}=1.00 ; n=181)$. 

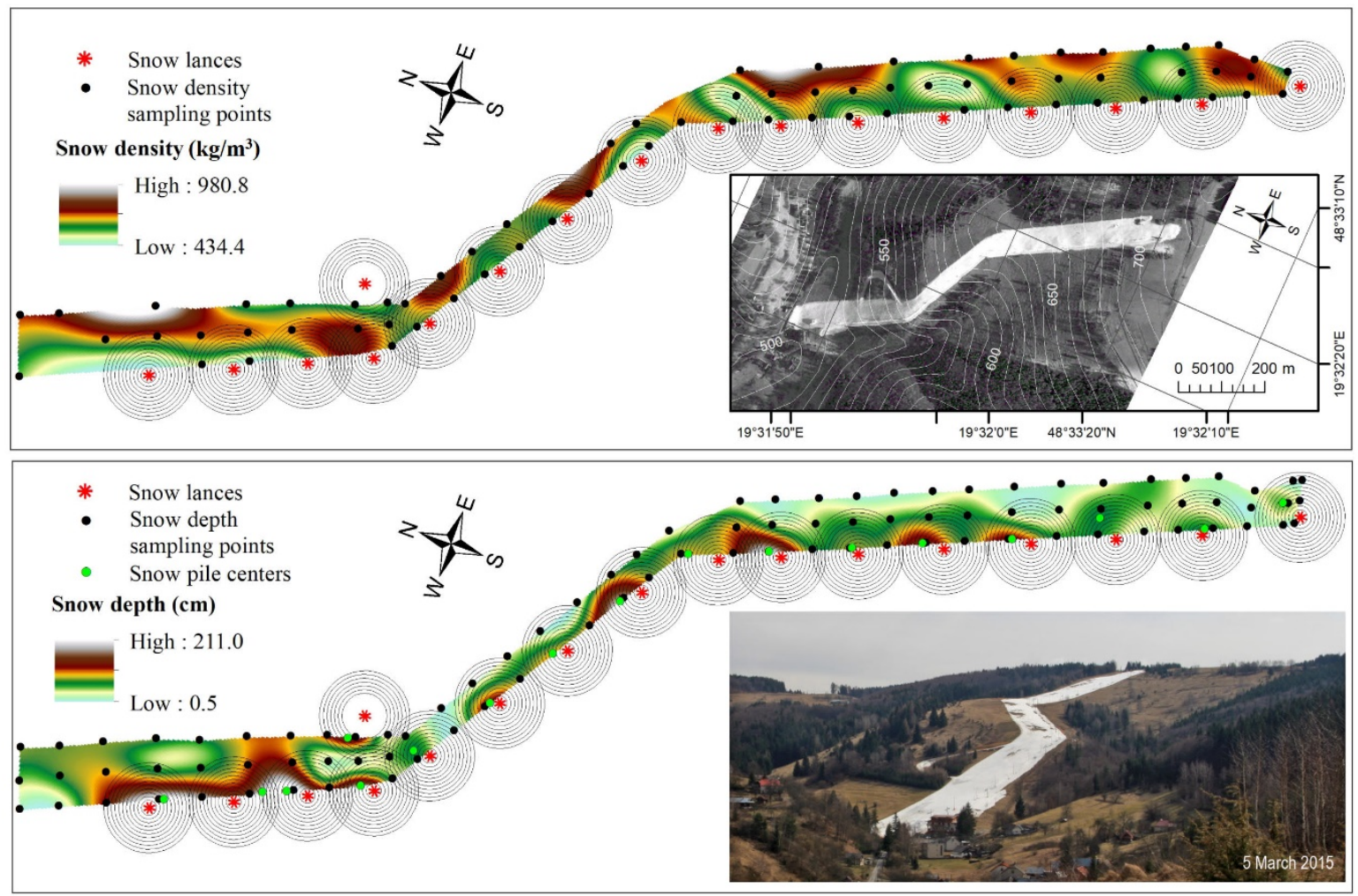

Figure 8. Snow densities and depth mapping of the ski piste snowpack for 5 March 2015, after the disappearance of natural snow from the off-piste sites. Displayed are snow pile centers (points of maximum snow depth within a $20 \mathrm{~m}$ radius around snow lances) and concentric circles around snow-making lances with $5 \mathrm{~m}$ spacing and maximum radii of $30 \mathrm{~m}$.

\section{Discussion}

\subsection{Snow Tube}

The difference in construction of designed MM snow tube resulted in a different method for snow sample extraction. While commonly used snow tubes are pushed and turned through the snowpack [5], the MM snow tube is hammered. Compared to most of the of commonly used snow tubes (VS-43, Standard Federal, SnowHydro) characterized by aluminum or non-opaque plastic bodies, the presence/absence of slots in the tube, and serrated cutting ends with teeth [43,44], the MM snow tube was made of stainless steel and designed with a keen cutting end and no slots in the body of the tube. This design reduces significant errors resulting from the presence of slots in the tube, which increase the snow density and the presence of a cutter with teeth, which underestimates the snowpack $[8,45,46]$. The MM snow tube slightly underestimated the density of the ski piste and natural snowpacks compared to the VS-43 snow tube, most likely due to its sharp and non-serrated cutting end. According to Bindon [47] and Beaumont [45], the sharper tube allows the cleaner extraction of snow samples from the snowpack and reduces possible overestimation by up to 50\%. The serrated cutting end of the VS-43 snow tube had difficulty penetrating through the ski piste snowpack when hammered, resulting in snow compression and higher density readings. These results coincide with the findings of Turčan and Loijens [48], who showed that the average snow density at depth can be artificially increased during snow tube penetration through the snowpack as the result of snow sample compression. The lower densities of the snow samples extracted by the MM tube were not the result of missed ice-soil plugs, as described by Dixon et al. [49] when comparing three snow tubes used in Canada, because the snow inside the examined tubes was pressed before removing it from the snowpack, and therefore ice-soil plugs were not missed. The underestimation of the MM snow tube with its small cutting end area $\left(13 \mathrm{~cm}^{2}\right)$ is in contrast to the findings of Peterson and 
Brown [46] and Farnes et al. [50], who found that snow tubes with small cutting end areas overestimate. These authors also found that snow tubes with cutting end areas $>20 \mathrm{~cm}^{2}$ had the least error. The results of abovementioned studies could differ due to different snowpack characteristics during snow surveys, mainly in terms of the hardness of the snow/ice layers in the snow profile and the snow grain size, which could influence penetration and consequently the accuracy of the measurements.

\subsection{Snow Density}

The mean minimal and mean maximal densities (excluding outliers) of uncompacted natural snow in the ski centers of Central Slovakia were $83 \mathrm{~kg} / \mathrm{m}^{3}$ and $411 \mathrm{~kg} / \mathrm{m}^{3}$, respectively. Mössner et al. [20] found comparable densities for seasonal natural snow, which varied from $100 \mathrm{~kg} / \mathrm{m}^{3}$ to $500 \mathrm{~kg} / \mathrm{m}^{3}$. Fassnacht [21] observed that prior to melt, the snow can attain a density of 300 to $500 \mathrm{~kg} / \mathrm{m}^{3}$, depending on the time period, meteorological conditions, and depth of the snow. As the present article shows, the density of new natural snowpack, maximally two days old, can vary between 78 to $289 \mathrm{~kg} / \mathrm{m}^{3}$. Singh [51] explained that the density of natural snow increased from 80 to $250 \mathrm{~kg} / \mathrm{m}^{3}$ when freshly fallen to a density of $300 \mathrm{~kg} / \mathrm{m}^{3}$ over 100 days due to equi-temperature snow metamorphism, during which the snow strength increases and compression occurs. This explanation coincides with our findings that the average density of the February snow was $263 \mathrm{~kg} / \mathrm{m}^{3}$ when this snow cover started to form in December. López-Moreno et al. [7], who analyzed snowpack characteristics in the Spanish Pyrenees (1517-3015 m a.s.l.), discovered an increase in snow density from $300 \mathrm{~kg} / \mathrm{m}^{3}$ in February to $455 \mathrm{~kg} / \mathrm{m}^{3}$ in April. These values are slightly higher than the mean values identified in the present paper, which could be explained by the longer durability of old, dense snow in the higher elevations of the Pyrenees or by the wider range of snow density values at lower elevations due to the occurrence of low-density new snow on previously melted areas. The current paper found a wide range of snow densities in April, which varied from 149 to $611 \mathrm{~kg} / \mathrm{m}^{3}$, that could be explained by new snow from the beginning of winter metamorphosing into snow from late winter. Jonas et al. [6] identified a comparable range of values at the end of the winter season for elevations below $1400 \mathrm{~m}$ a.s.l. (Swiss Alps). These authors also found a lower range of snow density values at higher elevations.

The present paper has demonstrated a classification of four snow types according to their mean densities (in descending order): ski piste snow (snowed/groomed snowpack), new artificial snow, uncompacted natural snow, and new natural snow. The findings of Rixen et al. [13,30] confirm the higher density of ski piste snow compared to uncompacted natural snow due to the intensive production of artificial snow and compaction of snow on the ski pistes; however, new artificial and natural snow were not examined in these studies. In the present article, the mean density of March snow on the snowed/groomed ski pistes was 2.4 times higher than the mean density of uncompacted natural snow beside pistes (635 versus $263 \mathrm{~kg} / \mathrm{m}^{3}$ ). Rixen et al. [24] found lower ratio in Swiss ski centers (elevation above $1500 \mathrm{~m}$ a.s.l.) in March (1.3 times; approximately 570 versus $430 \mathrm{~kg} / \mathrm{m}^{3}$; [30]), because of the lower density of ski piste snow and the higher density of natural uncompacted snow beside the piste, compared to present study. This difference can be explained by the lower elevation of the Slovakian ski pistes, where artificial snow has to be produced even at higher air temperatures [27] and where the continuous natural snowpack is present for a shorter duration compared to conditions at elevations above $1000 \mathrm{~m}$ a.s.l. [27]. A shorter continuous duration of the snowpack means a shorter time for snow metamorphism, during which the snow density increases [52]. The mean minimal and maximal densities of snow on the snowed and groomed ski pistes of Central Slovakian were 392 and $812 \mathrm{~kg} / \mathrm{m}^{3}$. Fauve et al. [53] and Federolf et al. [23] identified comparable minimums (400 and $\left.430 \mathrm{~kg} / \mathrm{m}^{3}\right)$, while their maximums were considerably lower $\left(600\right.$ and $\left.660 \mathrm{~kg} / \mathrm{m}^{3}\right)$. The all-season high maximal density of the ski piste snowpack in the studied ski centers could have resulted from a high density of artificial snow produced at the beginning of each winter season in all studied ski centers. The mean density of new artificial snow at the ski centers was $410 \mathrm{~kg} / \mathrm{m}^{3}$, while it ranged between 282 and $556 \mathrm{~kg} / \mathrm{m}^{3}$, on average. Melanie and Rixen [31] found a comparable range for the density of new artificial snow $\left(350\right.$ to $600 \mathrm{~kg} / \mathrm{m}^{3}$ ). The present study shows that the mean density of new artificial snow 
was 2.3 times higher than that of new natural snow. The higher density of artificial snow compared to natural snow results from its small grain size and subsequently higher degree of compaction [54].

\subsection{Snow Density versus Snow Depth}

High snow production at Košútka resulted in snow piles with average depths and distances from snow lances of $110 \mathrm{~cm}$ and $13 \mathrm{~m}$ down the slope, respectively. Spandre et al. [16], who examined ski piste snow from November 2015 to January 2016 near the Les 2 Alpes ski resort (Oisans Range, French Alps; elevation $1680 \mathrm{~m}$ a.s.l.), identified lower snow depths in the centers of snow piles at approximately half the distance from snow lances than found in this article, probably due an earlier winter season and the lower slopes of the ski piste $\left(5^{\circ}\right.$ versus $\left.20^{\circ}\right)$. The snow lances used in the studies were comparable, while a low mean hourly wind speed was observed during months with snow production, even at Košútka [27]. The presented article shows that snow depth decreases away from snow lances, on average. Spandre et al. [16] showed a decrease in the snow depth of piles that were approximately $7 \mathrm{~m}$ away from the snow lances.

The current article found a moderately strong negative correlation between the snow depth and density of the ski piste snowpack on 15 March, 2015, at Košútka. No one else has published anything on this relationship yet, in contrast to studies dealing with uncompacted natural snow [55]. Numerous studies cited by Lunberg et al. [55] that analyzed data on a regional or continental scale identified a positive correlation between the depth and density of natural snow. For example, a long-term survey done in Yakutia (USSR; [56]) showed an increase in the snow density of about $180 \mathrm{~kg} / \mathrm{m}^{3}$ per each meter of increased snow depth. The present article showed a decrease in ski piste snow density. Lopez Moreno et al. [7], who performed measurements at approximately $100 \mathrm{~m}$ intervals using a local scale in the Spain Pyrenees, found an inconsistent relation between snow depth and density (strong/weak and negative/positive correlations) and pointed out that snow depth alone explained as much variability in the snow density as any other variable (terrain characteristics). In any comparison with the present article, it is important to point out that the natural snowpack does not have such variability on a local scale [7], thereby bolstering the consistent relationship between snow depth and density in the case of the ski piste snowpack. The negative correlation between the snow depth and density on the ski piste could be explained by the occurrence of basal ice layers on the bottom of the snowpack, as found for Košútka by Mikloš et al. [2]. These authors found, that with lower snow depth, the higher thickness of basal ice layer or bare ice (ice instead of snow) can be expected at the end of winter when warm and frosty days alternates [2]. Thus, it could be assumed that as the depth of the snow above the basal ice layer decreases during melting, the depth average density of snowpack increases in Košútka until snow melted away and pure ice remained.

\section{Conclusions}

Compared to the commonly used VS-43 snow tube, the designed MM snow tube has a smaller diameter, higher wall thickness, and sharpened cutting end and is resistant to damage during snow sample extraction. The MM snow tube has proved to be suitable for sampling high-density snow, such as the snow found on snowed/groomed ski pistes, due to its precision, rugged construction, and short sampling time. The MM tube is not recommended for sampling snow of low density and depth due to the small diameter of the tube and hardly detectable sample weights. Four snow types occurring in at ski centers were classified according to their mean seasonal densities and are listed in descending order: ski piste snow, new artificial snow, uncompacted natural snow, and new natural snow. While the mean seasonal densities of these four snow types differ significantly, the ranges were similar between new natural and new artificial snow and between uncompacted natural snow and ski piste snow. The lowest density recorded for freshly fallen natural snow was slightly above zero, while the density of ski piste snow can reach the density of ice or higher if it is saturated with meltwater. The density of the seasonal snow increases at a comparable rate over the season at piste and off-piste sites. Therefore, snow metamorphosis changes are major factors driving the snow density 
increases, because densification by snow-grooming machines and skiers was relevant only for ski pistes. The increase in the snow density on pistes is less rapid due to the high initial density caused by artificial snow and snow compaction via snow-grooming vehicles and skiers. At the end of the winter season, the range of the snow density on the pistes is comparable with the wide seasonal range. At this time of melting period, the spatial variability of the snow density on the piste changes with snow depth and distance from the snow lances. The snow density increases as the snow depth decreases, while the snow depth decreases with greater distances from the snow lances. The basal ice layers increase depth average density of snowpack when snow above is melting, while the snow piles at almost half the distance of the snow lances' range occur on the piste until the end of season as result of high artificial snow production.

Author Contributions: M.M. designed the MM snow tube and conducted the main data collection, analyses, and writing; M.J. helped with data collection; J.S. (Jaroslav Skvarenina) and J.S. (Jana Skvareninova) provided overall guidance and supervised the study. All authors have read and agreed to the published version of the manuscript.

Funding: This work was accomplished as a part of VEGA projects No. 1/0500/19, 1/0111/18 of the Ministry of Education, Science, Research, and Sport of the Slovak Republic and the Slovak Academy of Science and the projects No. APVV-15-0425, APVV-18-0347 of the Slovak Research and Development Agency. The authors thank the agencies for their support.

Acknowledgments: Authors would like to extend their gratitude to Igor Mikloš for his help with the MM snow tube construction and production.

Conflicts of Interest: The authors declare no conflict of interest.

\section{Appendix A}

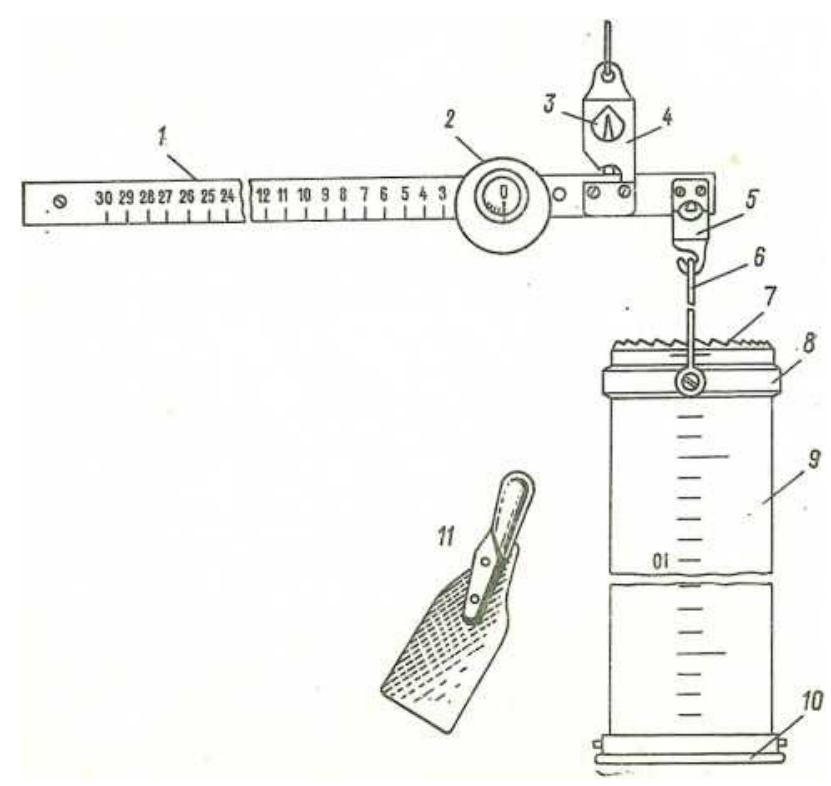

Figure A1. Assembly of the VS-43 snow tube with original mechanical scales and shovel. Scales: 1-metal ruler, 2-movable rider, 3-pointer, 4-suspension, 5-hook; Snow tube: 6-handle, 7-cutting end, 8-movable ring, 9-aluminum tube, 10-tube cover (cap), 11-a shovel. Source: [42,57]. Digital Kern HDB10K10N scales were used in the presented article instead of mechanical scales. 


\section{References}

1. Kumar, A. Seasonal snow cover. In Encyklopedia of Snow, Ice and Glaciers, 1st ed.; Singh, V.P., Singh, P., Haritashya, U.K., Eds.; Springer: Dordrecht, The Netherlands, 2011; pp. 974-975.

2. Mikloš, M.; Igaz, D.; Šinka, K.; Skvareninova, J.; Jančo, M.; Vyskot, I.; Skvarenina, J. Ski piste snow ablation versus potential infiltration (Veporic Unit, Western Carpathians). J. Hydrol. Hydromech. 2020, 68, 28-37. [CrossRef]

3. Barrett, T.P.; Adam, J.C.; Lettenmaier, D.P. Potential impacts of warming climate on water availability in snow-dominated regions. Nature 2005, 438, 303-309. [CrossRef] [PubMed]

4. Mikloš, M.; Vyskot, I.; Šatala, T.; Korísteková, K.; Jančo, M.; Skvarenina, J. Effect of forest ecosystems on the snow water equivalent in relation to aspect and elevation in the Hučava river watershed, Pol'ana Biosphere Reserve (Slovakia). Ekológia 2017, 36, 268-280.

5. Kinar, N.J.; Pomeroy, J.W. Measurement of the physical properties of the snowpack. Rev. Geophys. 2015, 53, 481-544. [CrossRef]

6. Jonas, T.; Marty, C.; Magnusson, J. Estimating the snow water equivalent from snow depth measurements in the Swiss Alps. J. Hydrol. 2009, 378, 161-167. [CrossRef]

7. López-Moreno, J.I.; Fassnacht, S.R.; Heath, J.T.; Musselman, K.N.; Revuelto, J.; Latron, J.; Morán-Tejeda, E.; Jonas, T. Small scale spatial variability of snow density and depth over complex alpine terrain: Implications for estimating snow water equivalent. Adv. Water Resour. 2013, 55, 40-52.

8. Goodison, B.; Ferguson, H.; McKay, G. Measurement and data analysis. In Handbook of Snow: Principles, Processes, Management and Use; Gray, D.M., Male, D.H., Eds.; Pergamon Press: Toronto, ON, Canada, 1981; pp. 191-274.

9. Church, J.E. Snow surveying: Its principles and possibilities. Geogr. Rev. 1933, 23, 529-563. [CrossRef]

10. Bartík, M.; Sitko, R.; Oreňák, M.; Slovik, J.; Skvarenina, J. Snow accumulation and ablation in disturbed mountain spruce forest in West Tatra Mts. Biologia 2014, 69, 1492-1501. [CrossRef]

11. Singh, A.K. Snow layer. In Encyklopedia of Snow, Ice and Glaciers, 1st ed.; Singh, V.P., Singh, P., Haritashya, U.K., Eds.; Springer: Dordrecht, The Netherlands, 2011; pp. 1059-1060.

12. Keller, T.; Pielmeier, C.; Rixen, C.; Gadient, F.; Gustafsson, D.; Stähli, M. Impact of artificial snow and ski-slope grooming on snowpack properties and soil thermal regime in a sub-alpine ski area. Ann. Glaciol. 2004, 38, 314-318. [CrossRef]

13. Rixen, C.; Haeberli, W.; Stoeckli, V. Ground temperatures under ski pistes with artificial and natural snow. Arct. Antarct. Alp. Res. 2004, 36, 419-427. [CrossRef]

14. Horner, R.A. Techniques for sampling sea-ice algae. In Polar Marine Diatoms; Medlin, L.K., Priddle, J., Eds.; British Antarctic Survey, Natural Environment Research Council: Cambridge, UK, 1990; pp. 19-23.

15. Koci, B.R.; Kuivinen, K.C. The PICO lightweight coring auger. J. Glaciol. 1984, 30, 244-245. [CrossRef]

16. Spandre, P.; François, H.; Thibert, E.; Moris, S.; George-Marcelpoil, E. Determination of snowmaking efficiency on a ski slope from observations and modelling of snowmaking events and seasonal snow accumulation. Cryosphere 2017, 11, 891-909. [CrossRef]

17. Meijer zu Schlochtern, M.P.; Rixen, C.; Wipf, S.; Cornelissen, J.H. Management, winter climate and plant-soil feedbacks on ski slopes: A synthesis. Ecol. Res. 2014, 29, 583-592. [CrossRef]

18. De Jong, C. Challenges for mountain hydrology in the third millennium. Front. Environ. Sci. 2015, 3, 38. [CrossRef]

19. Fierz, C.; Armstrong, R.L.; Durand, Y.; Etchevers, P.; Greene, E.; McClung, D.M.; Nishimura, K.; Satyawali, P.K.; Sokratov, S.A. The International Classification for Seasonal Snow on the Ground; IHP-VII Technical Documents in Hydrology No. 83, IACS Contribution No. 1; UNESCO-IHP: Paris, France, 2009; pp. 3, 63.

20. Mössner, M.; Innerhofer, G.; Schindelwig, K.; Kaps, P.; Schretter, H.; Nachbauer, W. Measurement of mechanical properties of snow for simulation of skiing. J. Glaciol. 2013, 59, 1170-1178. [CrossRef]

21. Fassnacht, S. Snow density. In Encyklopedia of Snow, Ice and Glaciers, 1st ed.; Singh, V.P., Singh, P., Haritashya, U.K., Eds.; Springer: Dordrecht, The Netherlands, 2011; 1045p, ISBN 978-90-481-2642-2.

22. Spandre, P.; François, H.; George-Marcelpoil, E.; Morin, S. Panel based assessment of snow management operations in French ski resorts. J. Outdoor Recreat. Tour. 2016, 16, 24-36. [CrossRef]

23. Federolf, P.; JeanRichard, F.; Fauve, M.; Lüthi, A.; Rhyner, H.-U.; Dual, J. Deformation of snow during a carved ski turn. Cold Reg. Sci. Technol. 2006, 46, 69-77. [CrossRef] 
24. Rixen, C.; Stoeckli, V.; Ammann, W. Does artificial snow production affect soil and vegetation of ski pistes? A review. Perspect. Plant. Ecol. 2003, 5, 219-230. [CrossRef]

25. Vido, J.; Tadesse, T.; Šustek, Z.; Kandrík, R.; Hanzelová, M.; Skvarenina, J.; Skvareninova, J.; Hayes, M. Drought occurrence in central european mountainous region (Tatra National Park, Slovakia) within the period 1961-2010. Adv. Meteorol. 2015, 2015, 1-8. [CrossRef]

26. Kohnová, S.; Rončák, P.; Hlavčová, K.; Szolgay, J.; Rutkowska, A. Future impacts of land use and climate change on extreme runoff values in selected catchments of Slovakia. Meteorol. Hydrol. Water Manag. 2019, 7, 47-55. [CrossRef]

27. Mikloš, M.; Jančo, M.; Korísteková, K.; Skvareninova, J.; Skvarenina, J. The Suitability of Snow and Meteorological Conditions of South-Central Slovakia for Ski Slope Operation at Low Elevation-A Case Study of the Košútka Ski Centre. Water 2018, 10, 907. [CrossRef]

28. Ďrigová, M.; Ballová, D.; Hlavčová, K. Analyses of Monthly Discharges in Slovakia Using Hydrological Exploratory Methods and Statistical Methods. Slovak J. Civ. Eng. 2019, 27, 36-43. [CrossRef]

29. Mind'aš, J.; Bartík, M.; Skvareninova, J.; Repiský, R. Functional effects of forest ecosystems on water cycle-Slovakia case study. J. For. Sci. 2018, 64, 331-339.

30. Rixen, C.; Freppaz, M.; Stoeckli, V.; Huovinen, C.; Huovinen, K.; Wipf, S. Altered snow density and chemistry change soil nitrogen mineralization and plant growth. Arct. Antarct. Alp. Res. 2008, 40, 568-575. [CrossRef]

31. Melanie, P.; Rixen, C. Management, winter climate and plant-soil feedbacks on ski slopes: A synthesis. Ecol. Res. 2014, 29, 583-592.

32. Mazúr, E.; Lukniš, M. Geomorfologické členenie SSR a ČSSR. Čast' Slovensko; Slovenská kartografia: Bratislava, Slovakia, 1986.

33. Vilček, J.; Koco, Š. Integrated index of agricultural soil quality in Slovakia. J. Maps 2018, 14, 68-76. [CrossRef]

34. Lapin, M.; Faško, P.; Melo, M.; Št'astný, P.; Tomlain, J. Climatic regions. In Landscape Atlas of the Slovak Republic, 1st ed.; Miklós, L., Hrnčiarová, T., Eds.; Slovak Environmental Agency: Bratislava, Slovakia, 2002; p. 99.

35. Vilček, J.; Skvarenina, J.; Vido, J.; Nalevanková, P.; Kandrík, R.; Skvareninova, J. Minimal change of thermal continentality in Slovakia within the period 1961-2013. Earth Syst. Dyn. 2016, 7, 735-744. [CrossRef]

36. SHMI (Slovak Hydrometeorologic Institute). Climate Atlas of Slovakia; Slovak Hydrometeorologic Institute: Banská Bystrica, Slovakia, 2015; 228p.

37. Hrvol', J.; Horecká, V.; Skvarenina, J.; Střelcová, K.; Skvareninova, J. Long-term results of evaporation rate in xerothermic Oak altitudinal vegetation stage in Southern Slovakia. Biologia 2009, 64, 605-609.

38. Hríbik, M.; Vida, T.; Skvarenina, J.; Skvareninova, J.; Ivan, L. Hydrological effects of Norway spruce and European beech on snow cover in a mid-mountain region of the Pol'ana Mts. J. Hydrol. Hydromech. 2012, 60, 319-332. [CrossRef]

39. Bartík, M.; Jančo, M.; Střelcová, K.; Skvareninova, J.; Skvarenina, J.; Mikloš, M.; Vido, J.; Waldhauserová, P.D. Rainfall interception in a disturbed montane spruce (Picea abies) stand in the West Tatra Mountains. Biologia 2016, 71, 1002-1008. [CrossRef]

40. Šatala, T.; Tesař, M.; Hanzelová, M.; Bartík, M.; Šípek, V.; Skvarenina, J.; Mind'áš, J.; Waldhauserová, P.D. Influence of beech and spruce sub-montane forests on snow cover in Pol'ana Biosphere Reserve. Biologia 2017, 72, 854-861. [CrossRef]

41. Skvarenina, J.; Tomlain, J.; Hrvol', J.; Skvareninova, J. Occurrece of dry and wet periods in altitudinal vegetation stages of West Carpathians in Slovakia: Time-Series Analysis 1951-2005. In Bioclimatology and Natural Hazards, 1st ed.; Střelcová, K., Matyas, C., Kleidon, A., Lapin, M., Matejka, F., Blazenec, M., Skvarenina, J., Holecy, J., Eds.; Springer: Dordrecht, The Netherlands, 2009; pp. 97-106.

42. Haberkorn, A. European Snow Booklet; COST Association: Brussels, Belgium, 2019; p. 363.

43. Crook, A.; Freeman, T. A comparison of techniques of sampling the arctic-subarctic snowpack in Alaska. In Proceedings of the 41st Annual Western Snow Conference, Grand Junction, CO, USA, 17-19 April 1973; Crook, A.G., Freeman, T.G., Eds.; Western Snow Conference: Brush Prairie, WA, USA, 1973; pp. 62-68.

44. McKay, G.A.; Blackwell, S. Plains snowpack water equivalent from climatological records. In Proceedings of the 29th Annual Western Snow Conference, Spokane, WA, 11-13 April 1961; Western Snow Conference: Brush Prairie, WA, USA, 1961; pp. 27-43. 
45. Beaumont RT. Field accuracy of volumetric snow samplers at Mt. Hood, Oregon. In Proceedings of the Conference on Physics of Snow and Ice, Sapporo, Japan, 14-19 August 1966; Institute of Low Temperature Science, Hokkaido University: Hokkaido, Japan, 1967; pp. 1007-1013.

46. Peterson, N.R.; Brown, A.J. Accuracy of snow measurements. In Proceedings of the 43rd Annual Western Snow Conference, Coronado, CA, 23-25 April 1975; Western Snow Conference Association: Coronado, CA, USA, 1975; Volume 43, pp. 1-9.

47. Bindon, H.H. The design of snow samplers for Canadian snow surveys. In Proceedings of the 21st Annual Eastern Snow Conference, Utica, NY, USA, 13-14 February 1964; pp. 23-28.

48. Turčan, J.; Loijens, H. Accuracy of snow survey data and errors in snow sampler measurements. In Proceedings of the 32nd Annual Eastern Snow Conference, Manchester, NH, USA, 6-7 February 1975; pp. 2-11.

49. Dixon, D.; Boon, S. Comparison of the SnowHydro snow sampler with existing snow tube designs. Hydrol. Process. 2012, 26, 2555-2562. [CrossRef]

50. Farnes, P.; Peterson, N.; Goodison, B.; Richards, R. Metrification of manual snow sampling equipment. In Proceedings of the 50th Western Snow Conference, Reno, Nevada, 19-23 April 1982; Western Snow Conference: Brush Prairie, WA, USA, 1982; pp. 120-132.

51. Singh, A.K. Snow metamorphism. In Encyklopedia of Snow, Ice and Glaciers, 1st ed.; Singh, V.P., Singh, P., Haritashya, U.K., Eds.; Springer: Dordrecht, The Netherlands, 2011; pp. 1060-1061.

52. Singh, A.K. Snow course. In Encyklopedia of Snow, Ice and Glaciers, 1st ed.; Singh, V.P., Singh, P., Haritashya, U.K., Eds.; Springer: Dordrecht, The Netherlands, 2011; p. 1032.

53. Fauve, M.; Rhyner, H.; Schneebeli, M. Preparation and Maintenance of Pistes: Handbook for Practitioners; Swiss Fed. for Snow and Avalanche Research SLF: Davos Dorf, Swizterland, 2002; 134p.

54. Jones, H.G.; Devarennes, G. The chemistry of artificial snow and its influence on the germination of mountain flora. In Biogeochemistry of Seasonal Snow-Covered Catchments, Proceedings of a Boulder Symposium, Boulder, CO, USA, 12-13 July 1995; IAHS: Wallingford, UK, 1995; Volume 228, pp. 355-360.

55. Lundberg, A.; Richardson-Näslund, C.; Andersson, C. Snow density variations: Consequences for ground penetrating radar. Hydrol. Process. 2006, 20, 1483-1495. [CrossRef]

56. Gavrilèv, R.I. Zavisimost' plotnosti snezhnogo pokrova v IAkutii ot ego vysoty (Dependence of the Density of the Snow Cover in Yakutai upon Its Thickness); Akademiia Nauk SSSR, Sibirskoe otdelenie, Institut merzlotovedeniia, Protsessy teplo-i massoobmena v merzlykh gornykh porodakh: Nauka, Moscow, 1965; pp. 45-49.

57. Losev, A.P. Praktikum po agroklimaticheskomu obespecheniyu rastenievodstva. In Workshop on Agro-Climatic Security Crop; Gidrometeoizdat: Saint Petersburg, Russia, 1994.

Publisher's Note: MDPI stays neutral with regard to jurisdictional claims in published maps and institutional affiliations.

(C) 2020 by the authors. Licensee MDPI, Basel, Switzerland. This article is an open access article distributed under the terms and conditions of the Creative Commons Attribution (CC BY) license (http://creativecommons.org/licenses/by/4.0/). 